\title{
Disease and Intolerability Documentation in Electronic Patient Records
}

\author{
Henk Buurma, Peter AGM De Smet, Martine Kruijtbosch, and Antoine CG Egberts
}

\begin{abstract}
BACKGROUND: Documentation of diseases and intolerabilities in electronic patient records (EPRs) in pharmacies is needed to produce an alert in case a contraindicated medicine is prescribed. Limited research is available concerning EPRs in pharmacies.

OBJECTIVE: To study the prevalence and quality of documentation of diseases and intolerabilities in EPRs in a sample of Dutch community pharmacies.

METHODS: Each participating pharmacy $(\mathrm{N}=79)$ collected data on one day in May 2003 for each patient enrolled into the study ( $\mathrm{N}=$ 687) concerning demographics, drug use, and documentation of diseases and intolerabilities.

RESULTS: In $57.4 \%$ of the EPRs, at least one disease and, in $7.9 \%$, at least one intolerability was documented. Higher age, number of drugs used, and chronic disease score were associated with any documentation of a disease/intolerability in the EPR. The highest sensitivity scores (completeness) were found for diabetes (84.7\%), asthma/chronic obstructive pulmonary disease (strict definition: $75.9 \%$ ), and hypothyroidism (75.0\%). Rather low values were found for prostatic hyperplasia (55.6\%) and heart failure (29.4\%). The positive predictive value (reliability) was high for hypothyroidism (100\%) and diabetes (87.1\%).

CONCLUSIONS: In a selection of Dutch pharmacies, at least one documented disease and/or intolerability was found in the EPR of almost $60 \%$ of the patients. Certain diseases were documented to a relatively high degree; others had poorer levels of documentation. For optimal surveillance of drug-disease interactions in pharmacies, the frequency and quality of disease and intolerability documentation need further improvement.
\end{abstract}

KEY WORDS: electronic patient record; pharmaceutical care, quality.

Ann Pharmacother 2005;39:1640-6.

Published Online, 13 Sept 2005, www.theannals.com, DOI 10.1345/aph.1G071

$\mathrm{T}$ he occurrence of drug-related problems (DRPs) has been the subject of several studies ${ }^{1,2}$ and is part of the public debate about patient safety and medication errors. ${ }^{3}$ Pharmacists can play a major role in the detection and prevention of DRPs and medication errors. ${ }^{4-8}$

Information technology in Dutch community pharmacies commenced 30 years ago with the electronic recording of simple patient data (eg, gender, age, address) and documentation of drugs dispensed to the patient. Thereafter, a medication surveillance program was introduced enabling the pharmacist to check for several potential DRPs, especially dosing problems, drug-drug interactions, and duplicate medications. With the documentation of clinical data in the electronic patient record (EPR), which included diseases and intolerabilities, it became possible to check for drug-disease interactions and drug intolerabilities (including allergies). ${ }^{7}$ These are considered important and preventable DRPs. ${ }^{8-11}$

Author information provided at the end of the text.
Dutch pharmacy medication surveillance software can advise the pharmacist to document a certain disease (eg, diabetes) for a specific patient based on a dispensed medication (eg, insulin). It can form part of a network linking several pharmacies with each other and/or with practices of general practitioners (GPs). It is, however, the pharmacist who has to decide whether to document the disease in question. In addition, clinical information provided by the prescriber or patient may lead to documentation of relevant clinical information by the pharmacist. After having documented the specific disease or intolerability, each new prescription is checked against the database for drug-disease interactions, leading to an alert on the computer screen in case of a relevant interaction (ie, contraindication).

Adequate documentation of relevant diseases and intolerabilities is thus essential for this type of medication surveillance. A limited amount of research has, however, been conducted on the magnitude, nature, and quality of the documentation of diseases and intolerabilities in the EPRs in pharmacies. This is in contrast to practices of 
GPs, where a considerable quantity of research regarding documentation in EPRs has been performed. ${ }^{12-15}$

We therefore studied the prevalence, nature, and quality of documentation of diseases and intolerabilities in EPRs in a sample of Dutch community pharmacies that were considered a vanguard in possessing the best possibilities for using the EPR. Additionally, we were interested in identifying determinants related to the documentation of any disease and/or intolerability in the EPR.

\section{Methods}

\section{Setting and Population}

All Dutch community pharmacies using the Pharmacom information technology system, particularly the Care Concept Electronic Programme ${ }^{16}$ $(\mathrm{N}=455)$ were invited to participate in this study in 2003, of which 79 $(17.4 \%)$ were ultimately enrolled. All participating pharmacies received a pretested study protocol, and the coordinating research center was available for questions. On one predetermined day in May 2003, each participating pharmacy randomly enrolled patients by using a predefined procedure that selected $1(2.5 \%)$ of every 40 patients to whom a prescription had been dispensed that day.

The procedure selected the highest prescription number ending with a 9 on the study day (eg, 4909) followed by all prescriptions, each separated by 40 prescriptions (eg, 4869,4829 ). In case this procedure led to possible inclusion of the same patient more than once, another patient was included according to the procedure described in the protocol. The inclusion procedure selected only patients who were prescribed drugs (n $=687$ ); 3 patients who had been dispensed other products (eg, incontinence material) were excluded from data analysis.

\section{COLLECTION AND CLASSIFICATION OF DATA}

One registration form was used to collect basic characteristics of the participating pharmacy. On another form, the pharmacist documented patient-specific information (age, gender, current drug use), as well as clinical information (diseases, intolerabilities) that were recorded in the patient's EPR. The diseases and conditions that can be documented in the EPR using a specific code are listed in Appendix I.

Pharmacists were requested to send anonymous copies of the medication-dispensing history of each study patient. When data on the registration form concerning current drug use conflicted with the medicationdispensing history, it resulted in an alteration by the research team. If necessary, consultation with the pharmacist was required in these cases. In the case of questions arising from the registration forms, the pharmacist was contacted as well.

All medicines were classified into therapeutic groups using the Anatomical Therapeutic Chemical (ATC) classification of the World Health Organization Collaborating Center for Drug Statistics Methodology. For each patient, the chronic disease score (CDS), a validated measure of the chronic disease status, was determined based upon the drugs used on the study day. ${ }^{17}$

\section{DATA ANALYSIS}

Data were entered into a database (Microsoft Access 2000) and analyzed using standard descriptive data analysis (SPSS version 10.0). Logistic regression analysis was used to measure the association between characteristics and recording of diseases and intolerabilities in the EPR.

For the assessment of the quality of the documentation of disease information in the EPR, the use of certain drugs was considered as a proxy parameter for the presence of a disease. This definition of the disease served as the "gold standard" when calculating the quality parameters. Electronic prescription data have become accepted as sensitive and highly predictive for diagnosis validation when used appropriately. ${ }^{18,19}$ Documentation of the disease in the EPR was considered the diagnostic test. As was done for diagnostic tests, sensitivity (completeness) and positive predictive value (accuracy) were calculated. ${ }^{13-15}$ The quality assessment was performed for diseases that were frequently encountered in the study population and/or with a high level of relevance as a contraindication for the use of certain drugs. In Appendix II, these diseases are presented as well as the proxy used for it, based upon current drug use (ATC codes).

\section{Results}

The participating 79 pharmacies comprised almost 5\% of all Dutch pharmacies ( 1700). Compared with the average Dutch pharmacy, these pharmacies had advanced possibilities for using the EPR, had slightly more personnel, participated in more structured meetings with GPs, and were more often equipped with a certified Quality Systema ( $33 \%$ vs $11 \%$ ). There was a large variation among pharmacies with respect to the daily number of prescriptions and the number of pharmacists and assistants, which reflects the fact that both small and large institutions participated in the study.

Data from 687 patients were collected (average 8.7 pts./pharmacy, range 3-17). The characteristics of these patients are presented in Table 1 .

In the EPR of all selected patients, a total number of 973 diseases and intolerabilities were documented. At least one documented disease and/or intolerability was found in the EPR of $59.8 \%$ of the patients $(n=411$; Table 2$)$. For several patients, more than one disease and/or intolerability was registered: more than one-third (34.6\%) had $\geq 3$ registered items. The most frequently documented diseases were hypertension, asthma/chronic obstructive pulmonary disease (COPD), hypercholesterolemia, depression, angina pectoris, and diabetes types 1 and 2. In the EPR of 7.9\% of the patients, at least one intolerability for a certain drug (group) was documented, especially antibiotics and analgesics.

Adjusted for all other variables, we found that older people ( $>55 \mathrm{y}$ ), patients using $\geq 3$ drugs, and those with a chronic disease score $\geq 1$ had a higher probability for any documentation of a disease/intolerability in their respective EPR (Table 3). The use of several drugs, such as cardiovascular, blood and blood organ, nervous system, and respiratory system agents, was also associated with documentation of a disease/intolerability.

Concerning the quality of documentation, we found the highest sensitivity scores (completeness) for diabetes, asth$\mathrm{ma} / \mathrm{COPD}$ (strict definition), and hypothyroidism (Table 4). A rather low value was found for the documentation of prostatic hyperplasia and a remarkably low one for heart failure. The positive predictive value, representing accuracy, was $100 \%$ for hypothyroidism. Relatively high values were found for diabetes and all cardiovascular diseases. Low data were found for asthma/COPD (strict definition) and angina pectoris.

\footnotetext{
an the Netherlands, the national society of pharmacies (KNMP) developed the Dutch Pharmacy Standard (NAN) with general and pharmacy-specific rules. The NAN is based on general international standards. Third parties (eg, physicians, patients) advised the KNMP. Individual pharmacies can achieve certification when they apply these standards according to certain rules.
} 


\section{Discussion}

To our knowledge, no previous study has examined the prevalence, nature, and quality of disease documentation in the EPR performed within a sample of community pharmacies. In a systematic review evaluating the quality of EPRs in GP practices, the completeness (sensitivity) of documentation of a summary of all conditions considered ranged from 55 to $96 .{ }^{14}$ Our data concerning the investigated diseases are within this range except for heart failure. In the aforementioned review, sensitivity values for angina and diabetes were 40 and $74-100$, respectively. This is somewhat lower than or comparable with our data. The positive predictive value ranged from 96 to 100 for all con-

\begin{tabular}{|c|c|c|}
\hline Characteristic & $\begin{array}{c}\text { Pts. } \\
(n=687)\end{array}$ & $\begin{array}{c}\% \\
\text { (range) }\end{array}$ \\
\hline \multicolumn{3}{|l|}{ Gender $(n)$} \\
\hline female & 420 & 61.1 \\
\hline male & 267 & 38.9 \\
\hline \multicolumn{3}{|l|}{ Age $(y)$} \\
\hline mean, range & 55.5 & $0-97$ \\
\hline $0-40^{\mathrm{a}}$ & 153 & 22.3 \\
\hline $41-55$ & 167 & 24.3 \\
\hline $56-70$ & 178 & 25.9 \\
\hline$>70$ & 189 & 27.5 \\
\hline \multicolumn{3}{|l|}{ Current prescribers involved $(n)$} \\
\hline GP only & 459 & 66.8 \\
\hline specialist only & 55 & 8.0 \\
\hline GP and specialist & 155 & 22.6 \\
\hline other & 18 & 2.6 \\
\hline \multicolumn{3}{|l|}{ Drugs $(n)$} \\
\hline mean, range & 4.3 & $1-18$ \\
\hline $1-2$ & 250 & 36.4 \\
\hline $3-5$ & 244 & 35.5 \\
\hline$>5$ & 193 & 28.1 \\
\hline \multicolumn{3}{|l|}{ Drug group (ATC class) } \\
\hline cardiovascular system & 326 & 47.5 \\
\hline nervous system & 306 & 44.5 \\
\hline alimentary tract and metabolism & 251 & 36.5 \\
\hline blood and blood-forming organs & 190 & 27.7 \\
\hline respiratory system & 173 & 25.2 \\
\hline genital-urinary system and sex hormones & 145 & 21.1 \\
\hline musculoskeletal system & 137 & 19.9 \\
\hline dermatologicals & 124 & 18.0 \\
\hline general antiinfectives for systemic use & 63 & 9.2 \\
\hline sensory organs & 63 & 9.2 \\
\hline $\begin{array}{l}\text { systemic hormonal preparations, } \\
\text { excluding sex hormones }\end{array}$ & 53 & 7.7 \\
\hline antineoplastic and immunomodulating agents & 17 & 2.5 \\
\hline various & 8 & 1.2 \\
\hline $\begin{array}{l}\text { antiparasitic products, insecticides, and } \\
\text { repellents }\end{array}$ & 4 & 0.6 \\
\hline \multicolumn{3}{|l|}{ Chronic disease score ${ }^{b}$} \\
\hline 0 & 290 & 42.2 \\
\hline $1-3$ & 208 & 30.3 \\
\hline$>3$ & 189 & 27.5 \\
\hline \multicolumn{3}{|c|}{$\begin{array}{l}\text { ATC = Anatomical Therapeutic Chemical; GP = general practitioner. } \\
\text { aThirty-six patients were } \leq 16 \text { years of age. } \\
\text { bThe chronic disease score is a validated measure of the chronic dis- } \\
\text { ease status. This measure is based on expert opinion on the use of } \\
\text { drugs as a validated proxy for chronic diseases. }{ }^{17}\end{array}$} \\
\hline
\end{tabular}

ditions. For angina and diabetes, positive predictive value data of 100 and $99-100$ were revealed. ${ }^{14}$ Our data are lower, with the exception of hypothyroidism.

In our study, antibiotics in particular (40\% attributed to penicillins) and, to a lower extent, analgesics accounted for most of the intolerability documentations. In several studies, these agents, particularly antibiotics (mostly penicillins), are mentioned as the most common cause of reactions. ${ }^{20,21}$ In our study, intolerabilities that are not necessarily anaphylactic in nature were documented; those may not automatically lead to the same event if the documented drugs are given in the future.

A number of limitations to this study should not be ignored. As the participating pharmacies constituted a voluntary sample, there may have been a positive selection bias. In addition, it concerned a specific sample of Dutch pharmacies, which were considered as having advanced possibilities for using the EPR. It is therefore possible that the more patient- and quality-oriented pharmacies participated. On the other hand, both small and large pharmacies, located in different parts in the Netherlands, were included.

\begin{tabular}{|c|c|c|c|}
\hline \multicolumn{4}{|c|}{$\begin{array}{l}\text { Table 2. Prevalence of Disease and Intolerability } \\
\text { Documentation per Patient }\end{array}$} \\
\hline \multirow{2}{*}{$\begin{array}{l}\text { Category } \\
\text { (range of items/pt.) }\end{array}$} & \multicolumn{3}{|c|}{ Pts. with $\geq 1$ Item ${ }^{a}$ ( $N=687$ ) } \\
\hline & $\mathbf{n}$ & $\%$ & $95 \% \mathrm{Cl}$ \\
\hline $\begin{array}{l}\text { Disease and/or Intolerability } \\
(0-14)\end{array}$ & 411 & 59.8 & 56.1 to 63.5 \\
\hline $\begin{array}{l}\text { Disease } \\
(0-7)\end{array}$ & 394 & 57.4 & 53.6 to 61.1 \\
\hline hypertension & 155 & 22.6 & 19.5 to 25.9 \\
\hline asthma/COPD & 100 & 14.6 & 12.0 to 17.4 \\
\hline hypercholesterolemia & 76 & 11.1 & 8.8 to 13.7 \\
\hline depression & 73 & 10.6 & 8.4 to 13.2 \\
\hline angina pectoris & 72 & 10.5 & 8.3 to 13.0 \\
\hline diabetes types 1 and 2 & 70 & 10.2 & 8.0 to 12.7 \\
\hline dyspepsia & 47 & 6.8 & 5.1 to 9.0 \\
\hline ulcus pepticum & 43 & 6.3 & 4.6 to 8.3 \\
\hline tachyarrhythmia & 35 & 5.1 & 3.6 to 7.0 \\
\hline reflux esophagitis & 22 & 3.2 & 2.0 to 4.8 \\
\hline prostatic hyperplasia & 19 & 2.8 & 1.7 to 4.3 \\
\hline hypothyroidism & 18 & 2.6 & 1.6 to 4.1 \\
\hline thrombosis & 18 & 2.6 & 1.6 to 4.1 \\
\hline epilepsy & 14 & 2.0 & 1.1 to 3.4 \\
\hline heart failure & 10 & 1.5 & 0.7 to 2.7 \\
\hline psoriasis & 10 & 1.5 & 0.7 to 2.7 \\
\hline $\begin{array}{l}\text { Intolerability/allergy } \\
(0-14)\end{array}$ & 54 & 7.9 & 6.0 to 10.1 \\
\hline penicillin & 17 & 2.5 & 1.5 to 3.9 \\
\hline salicylates/NSAIDs & 12 & 1.7 & 0.9 to 3.0 \\
\hline sulfonamides & 7 & 1.0 & 0.4 to 2.1 \\
\hline tetracyclines & 7 & 1.0 & 0.4 to 2.1 \\
\hline nitrofuranes & 5 & 0.7 & 0.2 to 1.7 \\
\hline trimethoprim & 5 & 0.7 & 0.2 to 1.7 \\
\hline tramadol & 4 & 0.6 & 0.2 to 1.5 \\
\hline
\end{tabular}

COPD = chronic obstructive pulmonary disease; NSAIDs = nonsteroidal antiinflammatory drugs.

aIn the electronic patient records of all 687 selected patients, we found a total of 973 disease and intolerability documentations. 


\begin{tabular}{|c|c|c|c|c|}
\hline \multirow[b]{2}{*}{ Characteristic } & \multirow{2}{*}{$\begin{array}{c}\text { Documentation, } \\
N=411 \\
(100 \%)\end{array}$} & \multirow{2}{*}{$\begin{array}{l}\text { No } \\
\text { Documentation, } \\
N=276 \\
(100 \%)\end{array}$} & \multicolumn{2}{|c|}{ OR $(95 \% \mathrm{Cl})^{\mathrm{a}}$} \\
\hline & & & Crude & Adjusted $^{b}$ \\
\hline \multicolumn{5}{|l|}{ Patient related, $\mathrm{n}(\%)$} \\
\hline \multicolumn{5}{|l|}{ Gender } \\
\hline male & $165(40.1)$ & $102(37.0)$ & 1 (reference) & 1 (reference) \\
\hline female & $246(59.9)$ & $174(63.0)$ & 0.87 (0.64 to 1.20$)$ & $0.99(0.67$ to 1.45$)$ \\
\hline \multicolumn{5}{|l|}{ Age $(y)$} \\
\hline $0-40$ & $49(11.9)$ & $104(37.7)$ & 1 (reference) & 1 (reference) \\
\hline $41-55$ & $86(20.9)$ & $81(29.3)$ & 2.25 (1.43 to 3.55$)$ & 1.57 (0.95 to 2.61$)$ \\
\hline $56-70$ & $135(32.8)$ & $43(15.6)$ & $6.66(4.11$ to 10.80$)$ & $3.08(1.80$ to 5.31$)$ \\
\hline$>70$ & $141(34.3)$ & $48(17.4)$ & 6.24 (3.89 to 9.99$)$ & $2.02(1.16$ to 3.51$)$ \\
\hline \multicolumn{5}{|l|}{ Prescriber related, $\mathrm{n}(\%)$} \\
\hline GP only & $258(62.8)$ & $201(72.8)$ & 1 (reference) & 1 (reference) \\
\hline specialist only & $25(6.1)$ & $30(10.9)$ & $0.65(0.37$ to 1.14$)$ & $0.58(0.30$ to 1.11$)$ \\
\hline both GP and specialist & $121(29.4)$ & $34(12.3)$ & 2.77 (1.82 to 4.23$)$ & $1.16(0.71$ to 1.91$)$ \\
\hline other & $7(1.7)$ & $11(4.0)$ & $0.50(0.19$ to 1.30$)$ & $0.49(0.16$ to 1.50$)$ \\
\hline \multicolumn{5}{|l|}{ Drugs in use, $\mathrm{n}(\%)$} \\
\hline $1-2$ & $88(21.4)$ & $162(58.7)$ & 1 (reference) & 1 (reference) \\
\hline $3-5$ & $156(38.0)$ & 88 (31.9) & 3.26 (2.26 to 4.72$)$ & 1.74 (1.12 to 2.69$)$ \\
\hline$>5$ & $167(40.6)$ & $26(9.4)$ & $11.82(7.26$ to 19.26$)$ & $3.91(2.00$ to 7.63$)$ \\
\hline \multicolumn{5}{|l|}{ ATC class $^{c}$} \\
\hline cardiovascular system & & & 5.23 (3.73 to 7.34$)$ & \\
\hline nervous system & & & 2.10 (1.53 to 2.87$)$ & \\
\hline alimentary tract and metabolism & & & $3.96(2.78$ to 5.66$)$ & \\
\hline blood and blood-forming organs & & & $4.05(2.70$ to 6.05$)$ & \\
\hline respiratory system & & & 2.03 (1.40 to 2.95$)$ & \\
\hline genital-urinary system and sex hormones & & & $0.47(0.32$ to 0.68$)$ & \\
\hline musculoskeletal system & & & $1.02(0.69$ to 1.49$)$ & \\
\hline dermatologicals & & & 1.05 (0.70 to 1.56$)$ & \\
\hline general antiinfectives for systemic use & & & $0.59(0.35$ to 0.99$)$ & \\
\hline sensory organs & & & $1.40(0.81$ to 2.42$)$ & \\
\hline systemic hormonal preparations, excluding sex hormones & & & 3.60 (1.73 to 7.49$)$ & \\
\hline antineoplastic and immunomodulating agents & & & 1.65 (0.57 to 4.73$)$ & \\
\hline various & & & $4.81(0.59$ to 39.27$)$ & \\
\hline antiparasitic products, insecticides, and repellents & & & $0.68(0.10$ to 4.84$)$ & \\
\hline \multicolumn{5}{|l|}{ Chronic disease score } \\
\hline 0 & $98(23.8)$ & $192(69.6)$ & 1 (reference) & 1 (reference) \\
\hline $1-3$ & $154(37.5)$ & $54(19.6)$ & 5.59 (3.77 to 8.29$)$ & $3.48(2.26$ to 5.37$)$ \\
\hline$>3$ & $159(38.7)$ & $30(10.9)$ & 10.38 (6.56 to 16.45$)$ & $3.22(1.73$ to 5.98$)$ \\
\hline \multicolumn{5}{|c|}{$\begin{array}{l}\text { ATC = Anatomical Therapeutic Chemical; GP = general practitioner. } \\
\text { aBold values indicate statistical significance. } \\
\text { bAdjusted for all other variables, except ATC class. } \\
\text { 'Reference, all but respected code. }\end{array}$} \\
\hline
\end{tabular}

\begin{tabular}{|c|c|c|c|c|}
\hline Disease & $\begin{array}{c}\text { Prevalence of } \\
\text { Disease, } \\
\mathrm{N}=687(100 \%)\end{array}$ & $\begin{array}{c}\text { Prevalence of } \\
\text { Documentation, } \\
\mathrm{N}=687(100 \%)\end{array}$ & $\begin{array}{l}\text { Sensitivity } \\
(95 \% \mathrm{Cl})\end{array}$ & $\begin{array}{l}\text { PPV, \% } \\
(95 \% \text { Cl) }\end{array}$ \\
\hline Diabetes types 1 and 2 & $72(10.5)$ & $70(10.2)$ & 84.7 (74.7 to 91.2$)$ & 87.1 (77.3 to 93.1$)$ \\
\hline Asthma/COPD strict definition & $29(4.2)$ & $100(14.6)$ & 75.9 (57.9 to 87.8$)$ & 22.0 (15.0 to 31.1$)$ \\
\hline Asthma/COPD broad definition & $99(14.4)$ & $100(14.6)$ & 68.7 (59.0 to 77.0$)$ & 68.0 (58.3 to 76.3$)$ \\
\hline Angina pectoris & $30(4.4)$ & $72(10.5)$ & 66.7 (48.8 to 80.8$)$ & 27.8 (18.8 to 39.0$)$ \\
\hline Heart failure & $17(2.5)$ & $10(1.5)$ & 29.4 (13.3 to 53.1$)$ & 50.0 (23.7 to 76.3$)$ \\
\hline All cardiovascular diseases & $326(47.5)$ & $229(33.3)$ & $65.0(59.7$ to 70.0$)$ & 92.6 (88.4 to 95.3$)$ \\
\hline Prostatic hyperplasia & $18(2.6)$ & $19(2.8)$ & 55.6 (33.7 to 75.4$)$ & 52.6 (31.7 to 72.7$)$ \\
\hline Hypothyroidism & $24(3.5)$ & $18(2.6)$ & $75.0(55.1$ to 88.0$)$ & $100.0(82.4$ to 100.0$)$ \\
\hline
\end{tabular}


Secondly, we considered current drug use as a proxy for having the disease concerned. ${ }^{18,19}$ In studies concerning GP electronic records, this method of drug-morbidity pairing has frequently been used. It is a simple measure; however, it will not always provide precise matching, and $100 \%$ may not be a reasonable absolute target. ${ }^{22}$ The only patients included were those being pharmacologically treated. Patients not yet pharmacologically treated, such as in the case of diabetes, but for whom adequate surveillance of drug-disease interactions is also relevant, could not be included. Sensitivity estimates are therefore likely to be positively biased.

We used different types of drug-morbidity pairing. Three diseases have an almost unambiguous relationship with currently used medication: diabetes, hypothyroidism, and prostatic hyperplasia. This suggests the highest integrity of sensitivity and positive predictive value data among the investigated diseases, bearing in mind the abovementioned limitation. We found relatively high, but still improvable, values concerning diabetes and hypothyroidism, but low values regarding prostatic hyperplasia. These diseases could be used as performance indicators concerning the documentation of diseases in the EPR.

Data concerning completeness and accuracy of recording need more consideration regarding the other diseases. There are 2 diseases with a rather restricted definition: asthma/COPD strict and angina pectoris (Appendix II). We may conclude that there is an almost unambiguous relationship between these diseases and the defined and currently used medications. We may have obtained a relatively clear impression about the completeness of recording (sensitivity) with these patients, indicating that completeness is also a good quality indicator. The accuracy represented by a positive predictive value of only $22 \%$ and $28 \%$ provides a rather contrasting picture. These low and unreliable data are understandable, however, because there are more drugs related to asthma/COPD or angina pectoris for which the pharmacist documented the disease in the EPR. As a result, there is an abundance of disease coding leading to a low positive predictive value.

We used 2 broad definitions concerning a disease: asth$\mathrm{ma} / \mathrm{COPD}$ broad and all cardiovascular diseases. We found reasonable but not high sensitivity values for both diseases. The broad definition will provide favorable opportunities for matching documentation in the EPR with the disease. On the other hand, pharmacists may have been reluctant to document the diseases in case of incidental use or first use (eg, sympathomimetic agents) or because they were not sure about the exact indication (eg, with cardiovascular disease). For the same reasons, one will find a reasonable positive predictive value for asthma/COPD in this case.

Finally, we examined a disease (heart failure) for which the computer will not prompt for documentation based on current drug use. Hence in this case, the pharmacist is confronted with a relatively poor representation of the actual number of patients with heart failure. The only way to document the disease is by reviewing a patient's medication record and/or communicating with physicians or patients. For heart failure, not surprisingly, a very low sensitivity score was found, highly disadvantageous in terms of providing optimal pharmaceutical care.

We did not investigate the quality of drug intolerability documentation. There is the question of underreporting in the EPR. In a recent study, a prevalence of self-reported drug allergy of $7.8 \%$ was found. ${ }^{21}$ Our findings are comparable with the latter data. In contrast, many patients mistakenly believe that an increased sensitivity to known adverse effects is caused by allergy. This may lead to misclassification in the EPR, preventing the prescribing of a justifiable and possibly very essential medicine, such as penicillin. ${ }^{23}$

Our study shows that, for some diseases, the documentation is quite accurate, but for others the quality requires further improvement. Pharmacists should be aware of this, since complete documentation of information may help reduce iatrogenic risks. A program of assessments, feedback, and training may help to increase this awareness. In some studies with respect to medical EPRs, such programs, although uncontrolled, appear to improve data quality.22

To further develop adequate documentation of diseases, pharmacists should seek cooperation with physicians. This cooperation will improve patient data in the physician's practice as well. Joint EPRs for physicians and pharmacists should be encouraged. Furthermore, it may be advisable that physicians state the reason for prescribing on the prescription so that pharmacies can use that information for disease documentation and, hence, more efficient medication surveillance. Finally, pharmacists should more efficiently gather reliable information from patients, as patients with well-defined chronic conditions have an accurate recall of medical and drug usage history. ${ }^{24}$

To ensure optimal medication safety, pharmacies are responsible for a system of medication surveillance and, hence, for high-quality EPRs. There are various reasons: prescriber systems are not completely reliable, ${ }^{25}$ the contents are not always comparable to those of the pharmacy, ${ }^{26,27}$ physicians do not always react in a justified way, ${ }^{28}$ physicians do not always use all items provided in the medical record system, ${ }^{29}$ there might be a lack of awareness of allergies (and other adverse drug reactions that a patient has experienced), and a high degree of allergy alert overrides among physicians. ${ }^{20,30}$

Finally, we would like to argue that to have no alert is actually more problematic than a false alert. After all, by communicating with the patient (or prescriber), the signal for a disease-drug interaction can be verified. When the surveillance of this DRP is no longer appropriate, the disease must be removed from the EPR. In this respect, we would like to argue that lower sensitivity scores are of more (negative) importance than lower positive predictive values. On the other hand, however, it is important to limit the number of false-positive alerts since a high number may be a main reason to turn off alerts or to override them.

\section{Conclusions}

In a selected population of Dutch community pharmacies, at least one documented disease and/or intolerability 
was found in the EPR of almost $60 \%$ of the patients. There was an association between documenting a disease and/or intolerability and older people, patients using $\geq 3$ drugs, and those with a chronic disease score of $\geq 1$. Certain diseases, such as diabetes and hypothyroidism, were coded to a relatively high degree; others had poorer levels of coding, especially heart failure. For optimal surveillance of drug-disease interactions in pharmacies, the frequency and quality of disease and intolerability documentation need further improvement.

Henk Buurma PharmD, Director, SIR Institute for Pharmacy Practice Research, Leiden, Netherlands; Researcher, Department of Pharmacoepidemiology and Pharmacotherapy, Utrecht Institute for Pharmaceutical Sciences, Utrecht University, Utrecht, Netherlands Peter AGM De Smet PharmD PhD, Researcher, Scientific Institute of Dutch Pharmacists, The Hague, Netherlands; Professor, Department of Clinical Pharmacy, University Medical Centre St Radboud, Nijmegen, Netherlands

Martine Kruijtbosch MSc, Researcher, SIR Institute for Pharmacy Practice Research

Antoine CG Egberts PharmD PhD, Professor, Department of Pharmacoepidemiology and Pharmacotherapy, Utrecht Institute for Pharmaceutical Sciences, Utrecht University; Hospital Pharmacist, Midden-Brabant, TweeSteden Hospital and St. Elisabeth Hospital, Tilburg, Netherlands

Reprints: Dr. Buurma, Department of Pharmacoepidemiology and Pharmacotherapy, Utrecht Institute for Pharmaceutical Sciences, Utrecht University, PO Box 80.082, 3508 TB Utrecht, Netherlands, fax 3130 2539166,h.buurma@stevenshof.nl
We thank all 79 pharmacists who participated in the study. Special thanks to J Kappe, EN Reitsma, MM Tuijn, pharmacists; and G Meyvis, pharmacy technician, who helped in the design and implementation of the study.

\section{References}

1. Weingart SN, Wilson RM, Gibberd RW, Harrison B. Epidemiology of medical error. BMJ 2000;320:774-7.

2. Gandhi TK, Seger DL, Bates DW. Identifying drug safety issues: from research to practice. Int J Qual Health Care 2000;12:69-76.

3. Kohn LT, Corrigan JM, Donaldson MS, eds. To err is human. Building a safer health system. Washington, DC: National Academy Press, 1999.

4. Westerlund LT, Marklund BR, Handl WH, Thunberg ME, Allebeck P. Nonprescription drug-related problems and pharmacy interventions. Ann Pharmacother 2001;35:1343-9. DOI 10.1345/aph.1A065.

5. Bouvy ML, Buurma H, Egberts TC. Laxative prescribing in relation to opioid use and the influence of pharmacy-based intervention. J Clin Pharm Ther 2002;27:107-10.

6. Beney J, Bero LA, Bond C. Expanding the roles of outpatient pharmacists: effects on health services utilisation, costs, and patient outcomes Cochrane Database Syst Rev 2000;3:CD000336.

7. Buurma H, De Smet PA, van den Hoff OP, Egberts AC. Nature, frequency and determinants of prescription modifications in Dutch community pharmacies. Br J Clin Pharmacol 2001;52:85-91.

8. Buurma H, de Smet PA, Leufkens HG, Egberts AC. Evaluation of the clinical value of pharmacists' modifications of prescription errors. Br J Clin Pharmacol 2004;58:503-11.

9. Goldberg RM, Mabee J, Chan L, Wong S. Drug-drug and drug-disease interactions in the ED: analysis of a high-risk population. Am J Emerg Med 1996;14:447-50.

10. Hanlon JT, Schmader KE, Boult C, Artz MB, Gross CR, Fillenbaum $\mathrm{GG}$, et al. Use of inappropriate prescription drugs by older people. J Am Geriatr Soc 2002;50:26-34.

\begin{tabular}{|llll|}
\hline \multicolumn{2}{|c|}{ Appendix I. Diseases or Conditions that Can Be Documented in the Information Technology System of the Included Pharmacies } \\
\hline Angina pectoris & Diminished kidney function & Hyperthyroidism & Psoriasis \\
Angle-closure glaucoma & Diminished liver function & Hypothyroidism & Raynaud's phenomenon \\
Asthma/chronic obstructive pul- & Dyspepsia & Lactation & Reflux esophagitis \\
monary disease (both also sepa- & Endometrial cancer & Myasthenia & Sports \\
rately) & Endometriosis & Open-angle glaucoma & Tachycardia \\
Bipolar disorder & Epilepsy & Parkinson's disease & Tardive dyskinesia \\
Breast cancer & Glucose-6 phosphate dehydroge- & Peptic ulcer disease & Thrombosis \\
Contact lenses & nase deficiency & Porphyria & \\
Crohn's disease/ulcerative colitis & Gout & Pregnancy (divided into 3 trimes- \\
Depression & Heart failure & ters) & \\
Diabetes type 1 & Hypercholesterolemia & Prolonged QT interval syndrome \\
Diabetes type 2 & Hypertension & Prostatic hyperplasia & \\
\hline
\end{tabular}

\begin{tabular}{|c|c|}
\hline \multicolumn{2}{|r|}{ Appendix II. Diseases and Drugs Used as a Proxy for These Diseases } \\
\hline Disease & Drugs (ATC Codes) Used as a Proxy \\
\hline Diabetes types 1 and 2 & insulin $(\mathrm{A} 10 \mathrm{~A})$ and/or oral antidiabetics (A10B) \\
\hline Asthma/COPD strict definition & theophylline (R03DA04) and/or combination of long-acting sympathomimetics and corticosteroids (R03AK06/-07) \\
\hline Asthma/COPD broad definition & all asthma/COPD medication (R03) \\
\hline Angina pectoris & $\begin{array}{l}\text { nitrate sublingual spray (C01DA02) and/or sublingual isosorbide dinitrate tablet } 5 \mathrm{mg} \text {, both intended for use in } \\
\text { acute angina }\end{array}$ \\
\hline Heart failure & $\begin{array}{l}\text { loop diuretics (C03CA01/-02) and at least } 2 \text { medications from the following groups: (1) spironolactone (C03DA01), } \\
\text { (2) ACE inhibitor/angiotensin II antagonist, (3) specific } \beta \text {-blocker (C07AB02/-07/C07AG02), (4) digoxin (C01AA05) }\end{array}$ \\
\hline All cardiovascular diseases & all cardiovascular drugs $(\mathrm{C})$ \\
\hline Prostatic hyperplasia & $\begin{array}{l}\alpha_{1} \text {-adrenergic receptor blockers (G04CA01/-02/-03) and/or finasteride (G04CB01) (other } \alpha_{1} \text {-adrenergic receptor } \\
\text { blockers were excluded since they are also indicated for hypertension; however, they were not found in the cohort) }\end{array}$ \\
\hline Hypothyroidism & $\begin{array}{l}\text { levothyroxine (H03AA01); the combination with thioamides excluded since this combination is used for hyperthy- } \\
\text { roidism }\end{array}$ \\
\hline
\end{tabular}


11. Williams CM. Using medications appropriately in older adults. Am Fam Physician 2002;66:1917-24.

12. Mitchell E, Sullivan F. A descriptive feast but an evaluative famine: systematic review of published articles on primary care computing during 1980-97. BMJ 2001;322:279-82.

13. Hassey A, Gerrett D, Wilson A. A survey of validity and utility of electronic patient records in a general practice. BMJ 2001;322:1401-5.

14. Thiru K, Hassey A, Sullivan F. Systematic review of scope and quality of electronic patient record data in primary care. BMJ 2003;326:1070-2.

15. Jordan K, Porcheret M, Croft P. Quality of morbidity coding in general practice computerized medical records: a systematic review. Fam Pract 2004;21:396-412.

16. De Gier JJ. The Electronic Pharmaceutical Dossier: an effective aid to documenting pharmaceutical care data. Pharm World Sci 1996;18:241-3.

17. Von Korff M, Wagner EH, Saunders K. A chronic disease score from automated pharmacy data. J Clin Epidemiol 1992;45:197-203.

18. Klungel OH, de Boer A, Paes AH, Herings RM, Seidell JC, Bakker A. Agreement between self-reported antihypertensive drug use and pharmacy records in a population-based study in the Netherlands. Pharm World Sci 1999;21:217-20.

19. Monster TB, Janssen WM, de Jong PE, de Jong-van den Berg LT. Pharmacy data in epidemiological studies: an easy to obtain and reliable tool. Pharmacoepidemiol Drug Saf 2002;11:379-84.

20. Abookire SA, Teich JM, Sandige H, Paterno MD, Martin MT, Kuperman GJ, et al. Improving allergy alerting in a computerized physician order entry system. Proc AMIA Symp 2000:2-6.

21. Gomes E, Cardoso MF, Praca F, Gomes L, Marino E, Demoly P. Self-reported drug allergy in a general adult Portuguese population. Clin Exp Allergy 2004;34:1597-601.

22. Porcheret M, Hughes R, Evans D, Jordan K, Whitehurst T, Ogden H, et al. Data quality of general practice electronic health records: the impact of a program of assessments, feedback and training. J Am Med Inform Assoc 2004;11:78-86.

23. Shepherd GM. Hypersensitivity reactions to drugs: evaluation and management. Mt Sinai J Med 2003;70:113-25.

24. Kehoe R, Wu SY, Leske MC, Chylack LT. Comparing self-reported and physician-reported medical history. Am J Epidemiol 1994;139:813-8.

25. Fernando B, Savelyich BSP, Avery AJ, Sheikh A, Bainbridge M, Horsfield $\mathrm{P}$, et al. Prescribing safety features of general practices computer systems: evaluation using simulated test cases. BMJ 2004;328:1171-3.

26. Weingart SN, Toth M, Sands DZ, Aronson MD, Davis RB, Phillips RS. Physicians' decisions to override computerized drug alerts in primary care. Arch Intern Med 2003;163:2625-31.

27. Rahimtoola H, Timmers A, Dessing R, Hudson S. An evaluation of community pharmacy records in the development of pharmaceutical care in the Netherlands. Pharm World Sci 1997;19:105-13.

28. Laerum H, Ellingsen G, Faxvaag A. Doctors' use of electronic medical records systems in hospitals: cross sectional study. BMJ 2001;323:13448.

29. Loomis GA, Ries JS, Saywell RM, Thakker NR. If electronic medical records are so great, why aren't family physicians using them? J Fam Pract 2002;51:636-41.

30. Hsieh TC, Kuperman GJ, Jaggi T, Hojnowski-Diaz P, Fiskio J, Williams $\mathrm{DH}$, et al. Characteristics and consequences of drug allergy alert overrides in a computerized physician order entry system. J Am Med Inform Assoc 2004;11:482-91.

\section{EXTRACTO}

TRASFONDO: La documentación de enfermedades e intolerancias a medicamentos en expedientes electrónicos de pacientes (EPR, por sus siglas en inglés) de farmacias es necesaria para generar alertas en caso de que un medicamento contraindicado sea prescrito. Existen pocas investigaciones relacionadas al uso de EPRs en farmacias.
OBJETIVO: Estudiar la prevalencia y calidad de la documentación de enfermedades e intolerancias a medicamentos en EPRs de una muestra de farmacias de comunidad en Holanda.

MÉToDos: Cada farmacia participante $(\mathrm{N}=79)$ recopiló datos un día del mes de mayo de 2003 para cada paciente admitido al estudio $(\mathrm{N}=687)$ incluyendo datos demográficos, uso de medicamentos, y documentación de enfermedades e intolerancias.

RESULTADOS: En $57.4 \%$ y $7.9 \%$ de los EPRs, se documentó por lo menos una enfermedad o una intolerancia a medicamento, respectivamente. La documentación de una enfermedad o intolerancia en el EPR fue mayor en pacientes mayores de 55 años de edad, que utilizaban $\geq 3$ medicamentos, $y$ que tenían una puntuación de enfermedad crónica de uno o más. Las puntuaciones más altas de sensibilidad (cuán completa era la documentación) fueron para diabetes (84.7\%), asma/enfermedad obstructiva del pulmón (definición estricta; 75.9\%), e hipotiroidismo (75.0\%). Se encontraron valores bajos para hiperplasia prostática (55.6\%) y fallo cardíaco (29.4\%). El valor positivo de predicción (confiabilidad) fue alto para hipotiroidismo $(100 \%)$ y diabetes $(87.1 \%)$.

CONCLUSIONES: En una muestra de farmacias en Holanda, por lo menos una enfermedad o intolerancia a medicamentos se encontró en el EPR de cerca del $60 \%$ de los pacientes. Algunas enfermedades fueron más documentadas que otras. Para una vigilancia óptima de interacciones medicamento-enfermedad en farmacias de comunidad, la frecuencia y calidad de la documentación de enfermedades e intolerancias debe mejorarse.

Homero A Monsanto

\section{RÉSUMÉ}

CONTEXTE: La documentation des diagnostics et des intolérances aux médicaments dans les dossiers-patients électroniques (DPE) est nécessaire pour générer une alerte lorsqu'un médicament contre-indiqué est prescrit. Peu de recherches ont été effectuées sur l'utilisation des DPE en pharmacie.

OBJECTIF: Étudier la prévalence et la qualité de la documentation des diagnostics et intolérances dans les DPE d'un échantillon de pharmacies en Hollande.

MÉTHODES: Chacune des pharmacies participantes $(\mathrm{N}=79)$ a recueilli durant une journée en mai 2003 les données relatives à la démographie, l'utilisation des médicaments, les diagnostics, et les intolérances sur 687 sujets.

RÉSULTATS: Au moins un diagnostic a été noté dans 57.4\% des DPE contre seulement une intolérance dans 7.9\% des DPE. L'âge plus élevé, le nombre de médicaments, et les maladies chroniques ont été associées plus souvent avec une documentation dans le DPE. Le scores de sensitivité (complétude) les plus élevés ont été observés avec le diabète (84.7\%), l'asthme/MPOC (définition stricte; $75.9 \%$ ), et hypothyroïdie (75\%). Les valeurs les plus basses ont été relevées pour l'hyperplasie prostatique (55.6\%) et l'insuffisance cardiaque (29.4\%). Les valeurs prédictives positives (fiabilité) étaient élevées pour l'hypothyroïdie $(100 \%)$ et le diabète $(87.1 \%)$.

CONCLuSIONS: Dans un échantillon de pharmacies hollandaises, au moins un diagnostic et/ou une intolérance a été documentée chez environ $60 \%$ des patients. Certaines maladies ont été associées à un taux de documentation plus élevé, d'autres beaucoup moins. Afin d'optimiser la surveillance des contre-indications de médicaments, la documentation des diagnostics et des intolérances doit être améliorée.

Nicolas Paquette-Lamontagne 